Citation: Ramírez-Razo, K., CristóbalMartínez, A. L, Alvarado-Rosales, D., Serret-López, M., \& ArandaOcampo, S. (2022). Identification of Pseudomonas viridiflava, causal agent of onion (Allium cepa L.) bulb rot Agro Productividad. https://doi.org/10.32854/ agrop.v15il.2110

Editor in Chief: Dr. Jorge Cadena Iñiguez

Received: August 10, 2021.

Accepted: December 14, 2022.

Published on-line: February 5, 2022

Agro Productividad, 15(1). January. 2022. pp: 121-128.

This work is licensed under a Creative Commons Attribution-NonCommercial 4.0 International license.

\title{
Identification of Pseudomonas viridiflava, causal agent of onion (Allium cepa L.) bulb rot
}

\author{
Ramírez-Razo, Karina ${ }^{1}$; Cristóbal-Martínez, Ana L. ${ }^{1}$; Alvarado-Rosales, Dionicio ${ }^{1}$; \\ Serret-López, María ${ }^{1}$; Aranda-Ocampo, Sergio ${ }^{1 *}$ \\ 1 Colegio de Postgraduados, Km. 36.5 Carretera Federal México-Texcoco, Montecillo, Texcoco, Estado de \\ México, México, G.P. 56230. \\ * Correspondence: saranda@colpos.mx
}

\section{ABSTRACT}

Objective: To phenotypically and molecularly characterize and identify the causal agent of onion (Allium cepa L.) bulb rot in Morelos, Mexico.

Methodology: Fluorescent bacteria from onion bulb tissue with symptoms of rot were isolated; the LOPAT test was used to describe them and subsequently they were identified by partial 16S rRNA gene amplification. Pathogenicity in vegetables and plants was evaluated injecting a suspension with $108 \mathrm{CFU} \mathrm{mL} \mathrm{m}^{-1}$ of the pathogen.

Results: Phenotypic characterization and 16S rRNA nucleotide sequencing showed 100\% identity with Pseudomonas viridiflava as the causal agent of onion bulb rot. The pathogen caused infection in broccoli (Brassica oleracea L.), spring onion (Allium fistulosum L.), purple onion (Allium cepa L.), cauliflower (Brassica oleracea var. botrytis L.), leek (Allium porrum L.), and carrot (Daucus carota L.), as well as in plant species such as jalapeño pepper (Capsicum annuum var. annuum L.), bean (Phaseolus vulgaris L.), and tomato (Solanum lycopersicum L.).

Implications: This information is important for agriculture in Mexico. Pseudomonas viridiflava is a bacterial pathogen with high potential to infect new hosts. This is the first report of $P$. viridiflava causing onion rot in Mexico.

Conclusions: Pseudomonas viridiflava is the causal agent of onion bulb rot in Morelos, Mexico. Other vegetables (such as spring onions and leek) can be potential new hosts in Mexico.

Keywords: pectinolytic bacteria, $16 \mathrm{~S}$ rRNA, pathogenicity, vegetables.

\section{INTRODUCTION}

Onion (Allium cepa L.) is the second most important vegetable crop in Mexico. Its export - mainly to the United States - is valued at 3.5 million dollars per year (TecnoAgro, 2017). Pseudomonas viridiflava is a bacterial pathogen with a wide range of hosts; it is genetically included within the Pseudomonas syringae species complex which is the most important phytopathogenic bacteria worldwide (Mansfield et al., 2010; Bartoli et al., 2015). P. viridiflava populations are characterized by their pectinolytic activity and the lack of oxidase and arginine dihydrolase. This sets it apart from the P. syringae species complex, according to the LOPAT determinative test (levana - oxidase - potato rot - arginine dihydrolase - hypersensitivity in tobacco

[Nicotiana tabacum L.]) (Lelliot and Stead, 1966).

In other countries, $P$. viridiflava can cause rot in bulbs, stems, and fruits in a wide range of hosts. Currently, many of these hosts are crops of economic 
importance in Mexico, for example, vegetables and fruits such as: tomato (Solanum lycopersicum L.), pepper (Capsicum annum L.), melon (Cucumis melo L.) (Al-Karablieh et al., 2017), watermelon (Citrullus lanatus L.), carrot (Daucus carota L.), lettuce (Lactuca sativa L.) (Nuebling et al., 2016), bean (Phaseolus vulgaris L.) (González et al., 2003), grapes (Vitis vinifera L.) (Goumans and Chatzaki, 1998), and citrus (Beiki et al., 2016).

It also affects ornamental flowering plants, such as chrysanthemums (Chrysanthemum sp.) (Goumans and Chatzaki, 1998) and the family Rosaceae (Choi et al., 2020). Although $P$. viridiflava is considered an opportunistic pathogen that can survive as a saprophyte and epiphyte, records indicate that severe epidemics have caused significant economic losses in crops such as melon (Cucumis melo L.), tomato (Solanum lycopersicum L.), chrysanthemum (Chrysanthemum sp.) (Goumans and Chatzaki, 1998), onion (Allium sp.) (Gitaitis et al., 1998), celery (Apium graveolens L.) (Hunter and Cigna, 1981), carrot (Daucus carota L.) (Godfrey and Marshall, 2002), and potato (Solanum tuberosum L.) (Macagnan et al., 2007).

There are not many studies about onion bulb rot in Mexico. Bulbs with symptoms of rot - probably caused by a bacterial infection - were observed in field onion crops of the State of Morelos, Mexico. Therefore, the objective was to phenotypically and molecularly characterize and identify the causal agent of onion bulb rot, evaluating the in vitro pathogenicity in different vegetables and plants species under greenhouse conditions, as well as the in vitro sensitivity of the agent to the bactericide.

\section{MATERIALS AND METHODS}

\section{Pathogen isolation}

In 2019, Blanca Morelos variety onion bulbs with symptoms of rot were collected in field in the town of Cuautla, Morelos (18 48' 45" N; $\left.98^{\circ} 57^{\prime} 17^{\prime \prime} \mathrm{W}\right)$. The tissue samples were disinfected with $1 \%$ sodium hypochlorite for $1.0 \mathrm{~min}$ and washed three times with sterile distilled water. Tissue pieces $(0.5 \mathrm{~g})$ were stirred in $20 \mathrm{~mL}$ of saline solution $(0.85 \%$ $\mathrm{NaCl}$ ) for $1 \mathrm{~h} ; 20 \mu \mathrm{L}$ of this suspension were placed in plates with King's B (KB) culture medium and were incubated at $28{ }^{\circ} \mathrm{C}$ for $72 \mathrm{~h}$. Five fluorescent colonies from that suspension were isolated in ultraviolet light (25W Transilluminator TFL-40, California, USA); an isolate was selected for the subsequent study from one these colonies which had the same morphological characteristics.

\section{Physiological and biochemical characterization}

The fluorescent isolate was characterized for the LOPAT determinative test (Lelliot and Stead, 1966) and as per the protocols described by Schaad et al. (2001).

\section{In vitro sensitivity to bactericides}

Fifteen commercial bactericides (including four biological products) were evaluated using the dose recommended on the label and a modification of the procedure described by Klančnik et al. (2010): $100 \mu \mathrm{L}$ of a bacterial suspension were inoculated with $10^{8} \mathrm{CFU}$. $\mathrm{mL}^{-1}$ in $\mathrm{KB}$ medium and evenly distributed on the culture medium surface; then, 0.5$\mathrm{cm}$ wide filter paper discs, previously embedded in the bactericide solution, were placed. 
Plates were incubated for $72 \mathrm{~h}$ at $28^{\circ} \mathrm{C}$. Sensitivity was determined by the formation of a bacterial growth inhibition halo around the filter paper embedded with the bactericide.

\section{Molecular identification}

DNA was obtained from pure colonies using the CTAB method (William and Copeland, 2012). The partial 16S rRNA gene amplification was performed with the 8F:5'AGAGTTTGATCGTGGCTCAG-3' and 1492R:5'-GGTTACGTTGTTAGGACTT-3 primers and under the PGR conditions described by Weisburg (1991). Amplified fragments were sequenced in Macrogene Inc. (Korea); sequences were assembled and edited using the BioEdit Sequence Aligment Editor Software v.7.2.6 (Hall, 2005); the consensus sequence generated was compared with those contained in the National Center for Biotecnology Information (NCBI), with the BLAST nucleotide (dvV5) 2.10.0 option.

\section{Pseudomonas viridiflava pathogenicity}

Pathogenicity was evaluated in vitro in 15 vegetables and in 8 plants species, under greenhouse conditions. Vegetables were disinfected with soapy water, alcohol (70\%), and three washings with sterile distilled water. Inoculation was carried out by $100-\mu \mathrm{L}$ injection of suspension with $10^{8}$ CFU.mL ${ }^{-1}$. The treatments were kept in a humidity chamber and incubated at $28{ }^{\circ} \mathrm{C}$ for $72 \mathrm{~h}$. Each vegetable was inoculated with three repetitions. The control was inoculated with sterile distilled water. A completely randomized design was used. The plants species were sown in pots with a sterile substrate of agrolite, peat moss, and soil (2:2:1). They were kept in a greenhouse with $>60 \%$ relative humidity and a 25-30 ${ }^{\circ} \mathrm{C}$ temperature. A BD Plastipak hypodermic syringe was used to inoculate 0.5$\mathrm{mL}$ infiltration of a suspension with $10^{8} \mathrm{CFU} \cdot \mathrm{mL}^{-1}$ in the abaxial surface of three leaves, which were then kept in a greenhouse for $35 \mathrm{~d}$. Each plant species was inoculated with five repetitions. The control plants were inoculated with sterile distilled water.

\section{RESULTS AND DISGUSSION}

\section{Biochemical characterization}

The physiological and biochemical characterization of the onion bulb isolated strain showed high similarity to the metabolic profile described in other studies about $P$. viridiflava (Heydari et al., 2012; Sarris et al., 2012). Such characterization is $91 \%$ identical to the characteristics of the P. viridiflava ATCG 13223 (American Type Culture Collection) reference strain and nine isolates identified as $P$. viridiflava that cause rot in melon (AlKarabieth et al., 2017) (Table 1).

Using the LOPAT test, the isolated strain from onion produced a fluorescent pigment in $\mathrm{KB}$ medium and induced a hypersensitivity reaction in tobacco leaves; it also had negative results for oxidase and arginine dihydrolase; it did not produce levana and caused rot on potato slices.

According to Lelliot and Stead (1966), it was identified as $P$. viridiflava group II of Pseudomonas and had $100 \%$ similarity with P. viridiflava strain identified in tomato (Solanum lycopersicum L.), eggplant (Solanum melongena L.), celery (Apium graveolens L.), and amaranth (Amaranthus blitum L.) (Al-Karablieh et al., 2017). 
Table 1. Physiological and biochemical characterization, pathogenicity, and in vitro sensitivity to bactericides of Pseudomonas viridiflava isolated from onion.

\begin{tabular}{|c|c|c|c|c|c|c|}
\hline \multirow{3}{*}{$\begin{array}{l}\text { Test } \\
\text { Gram stain }\end{array}$} & \multirow{3}{*}{$\begin{array}{c}\begin{array}{c}P . \\
\text { viridiflava } \\
\text { onion }\end{array} \\
-\end{array}$} & \multirow{3}{*}{$\begin{array}{c}P . \\
\text { viridiflava } \\
\text { ATCC } \\
13223^{1} \\
\text { ND }\end{array}$} & \multirow{2}{*}{\multicolumn{2}{|c|}{$\begin{array}{c}\text { Pathogenicity } \\
\text { In vitro vegetables }\end{array}$}} & \multirow{2}{*}{\multicolumn{2}{|c|}{$\begin{array}{c}\text { In vitro sensitivity to bactericides } \\
\text { Antibiotics and coppers }\end{array}$}} \\
\hline & & & & & & \\
\hline & & & Garlic (Allium sativum L.) & - & $\begin{array}{l}\text { Agricultural Cuprimycin } \\
\text { (Oxytetracycline hydrochloride) }\end{array}$ & - \\
\hline Fluorescence & + & ND & $\begin{array}{l}\text { Broccoli (Brassica oleracea var. } \\
\text { Italica } \text { Plenck) }\end{array}$ & + & $\begin{array}{l}\text { Bactrol 2X (Streptomycin and } \\
\text { Oxytetracycline }\end{array}$ & - \\
\hline Levana & - & - & $\begin{array}{l}\text { Cambray onion (Allium fistulosum } \\
\text { L.) }\end{array}$ & + & $\begin{array}{l}\text { Cuprimycin } 17 \text { (Streptomycin } \\
\text { sulfate) }\end{array}$ & - \\
\hline Oxidase & - & - & Purple onion (Allium cepa L.) & + & $\begin{array}{l}\text { Agricultural Bactrimicin } \\
\text { (Oxytetracycline hydrochloride) }\end{array}$ & - \\
\hline Potato rot & + & + & Mushroom (Agaricus campestris Fr.) & - & $\begin{array}{l}\text { Cuprimycin } 500 \text { (Streptomycin } \\
\text { sulfate, oxytetracycline, and tribasic } \\
\text { copper sulfate monohydrate) }\end{array}$ & - \\
\hline Arginine dihydrolase & - & - & $\begin{array}{l}\text { Cauliflower (Brassica oleracea var. } \\
\text { botrytis L.) }\end{array}$ & + & Kasumin (Kasugamycin) & - \\
\hline Tobacco hypersensitivity & + & + & Ginger (Zingiber officinale L.) & - & $\begin{array}{l}\text { Final Bacter (Gentamicin sulfate } \\
\text { and Oxytetracycline hydrochloride) }\end{array}$ & + \\
\hline Catalase & + & ND & $\begin{array}{l}\text { Prickly pear cactus (Opuntia ficus } \\
\text { indica L. Miller) }\end{array}$ & - & $\begin{array}{l}\text { Phyton (Copper sulfate } \\
\text { pentahydrate) }\end{array}$ & - \\
\hline Gelatin hydrolysis & + & + & Pore (Allium porrum L.) & + & Copper oxychloride & - \\
\hline Nitrate reduction & - & + & Carrot (Daucus carota L.) & + & Biological & \\
\hline Starch hydrolysis & - & ND & Greenhouse plant & & Quatz IV (Quaternary ammonium) & + \\
\hline Oxidative/fermentative & $\mathrm{O}$ & $\mathrm{O}$ & $\begin{array}{l}\text { Amaranth (Amaranthus } \\
\text { hypochondriacus L.) }\end{array}$ & - & Bacter Best (Organic compounds) & - \\
\hline Use of: & & & Oats (Avena sativa L.) & - & $\begin{array}{l}\text { Bioxtermin (Bacillus thuringiensis } \\
\text { var. kurstaki) }\end{array}$ & - \\
\hline Glucose & + & + & $\begin{array}{l}\text { Jalapeño pepper (Capsicum annuит } \\
\text { var. annuит L.) }\end{array}$ & + & $\begin{array}{l}\text { Serenade powder (Bacillus } \\
\text { amyloliquefaciens) }\end{array}$ & + \\
\hline Lactose & + & ND & Bean (Phaseolus vulgaris L.) & + & Fungifree (Bacillus velezensis) & - \\
\hline Maltose & + & + & Tomato (Solanum lycopersicum L.) & + & & \\
\hline Cellobiose & + & ND & Purple corn (Zea mays L.) & - & & \\
\hline Trehalose & + & $\mathrm{ND}$ & Cucumber (Cucumis sativus L.) & - & & \\
\hline Dulcitol & - & ND & Weath (Triticum sp.) & - & & \\
\hline Inositol & + & + & & & & \\
\hline Sorbitol & + & + & & & & \\
\hline
\end{tabular}

${ }^{1}$ ATCG (American Type Culture Collection); Source: Al-Karabieth et al., 2017; ND=Test not determined; O=Oxidative metabolism.

\section{Molecular identification}

The BLAST analysis of the 16S rRNA nucleotide sequencing of the strain isolated from onion had 100\% identity with the RM207.1 a strain (16S rRNA gene) of Pseudomonas viridiflava (accession AY604845.1 4) which infected Arabidopsis thaliana (Figure 1). 


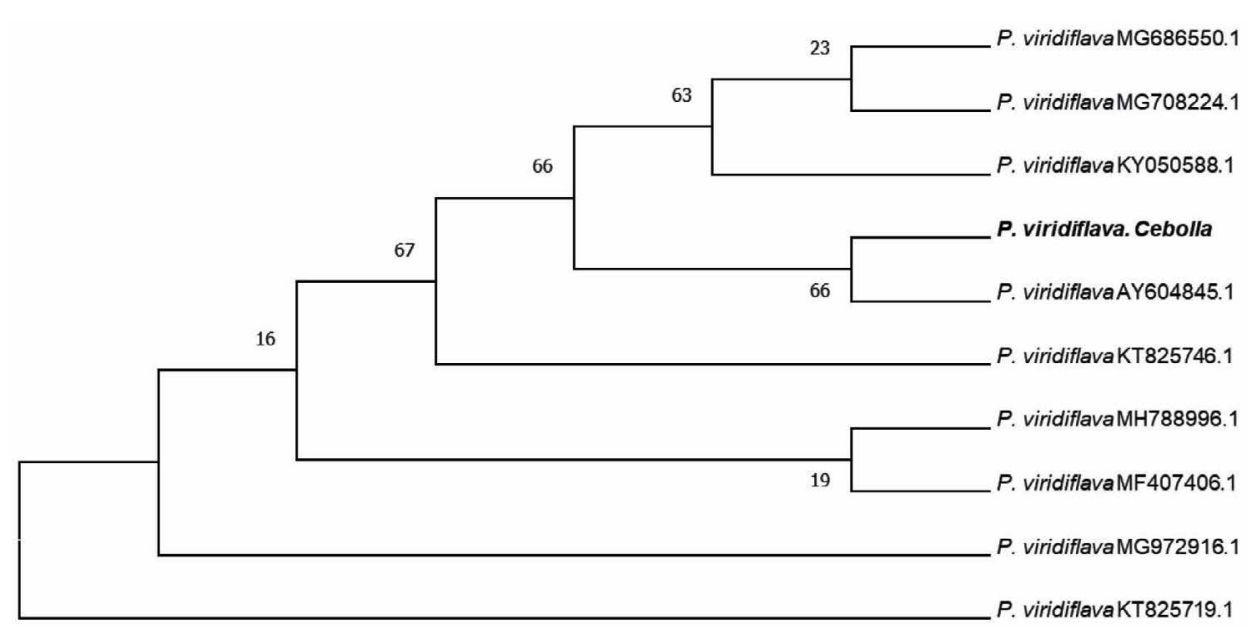

Figure 1. Consensus tree of Pseudomonas viridiflava isolated from onion based on partial 16S rRNA gene sequencing, using the Neighbor-Joining (NJ) method. Jukes-Cantor model 500 bootstrap replicates with nine sequences of the gene bank, aligned with the highest similarity index and coverage with Genbank sequences of related bacterial strains.

Other countries have reported significant economic losses as a consequence of the severe onion bulb rot caused by P. viridiflava (Gitaitis et al., 1998; Tsuji et al., 2021). In Mexico, Erwinia chrysanthemi (de Jesús et al., 2003) and recently Burkholderia gladioli (SerretLópez et al., 2020) were found to cause rot in onion bulbs. Consequently, this study is the first report of $P$. viridiflava as a causal agent of onion bulb rot in Mexico. P. viridiflava pathogenicity is mainly based on the production of the pectate lyase enzyme - which causes tissue maceration - and the expression of the type III secretion system for the virulence effector production within the host cell (Araki et al., 2007). P. viridiflava can survive as an epiphyte on onion leaves; therefore, it is considered as an inoculum source infecting under certain environmental and management conditions. The highest rot severity in onion was associated with epidemics occurring during long rain periods, under excessive fertilization conditions, and with high nitrogen content in leaves (Gitaitis et al., 2003). In the same way, different weed species surrounding onion crops have been identified as the main inoculum source for this pathogen (Gitaitis et al., 1998). P. viridiflava infection in citrus leaves was influenced by temperature, humidity, low oxygen concentrations, varietal susceptibility, and pathogen virulence (Beiki et al., 2016).

\section{Pseudomonas viridiflava pathogenicity}

The in vitro inoculation of $P$. viridfilava isolated from onion in Mexico caused rot in such vegetables as broccoli, spring onions, red onion, cauliflower, leek, and carrot, but not in ginger, mushrooms, garlic, and prickly pear (Table 1). These results are in line with previous reports (Goumans and Chatzaki, 1998); however, based on the bibliography and to our knowledge, this study results provide the first record of experimental rot in spring onions and leek by $P$. viridiflava. $P$. viridiflava caused symptoms of necrosis and foliar chlorosis in jalapeño pepper, tomato, and bean plants, as well as symptoms of plant stunting in beans (Table 1) (Figure 2). 

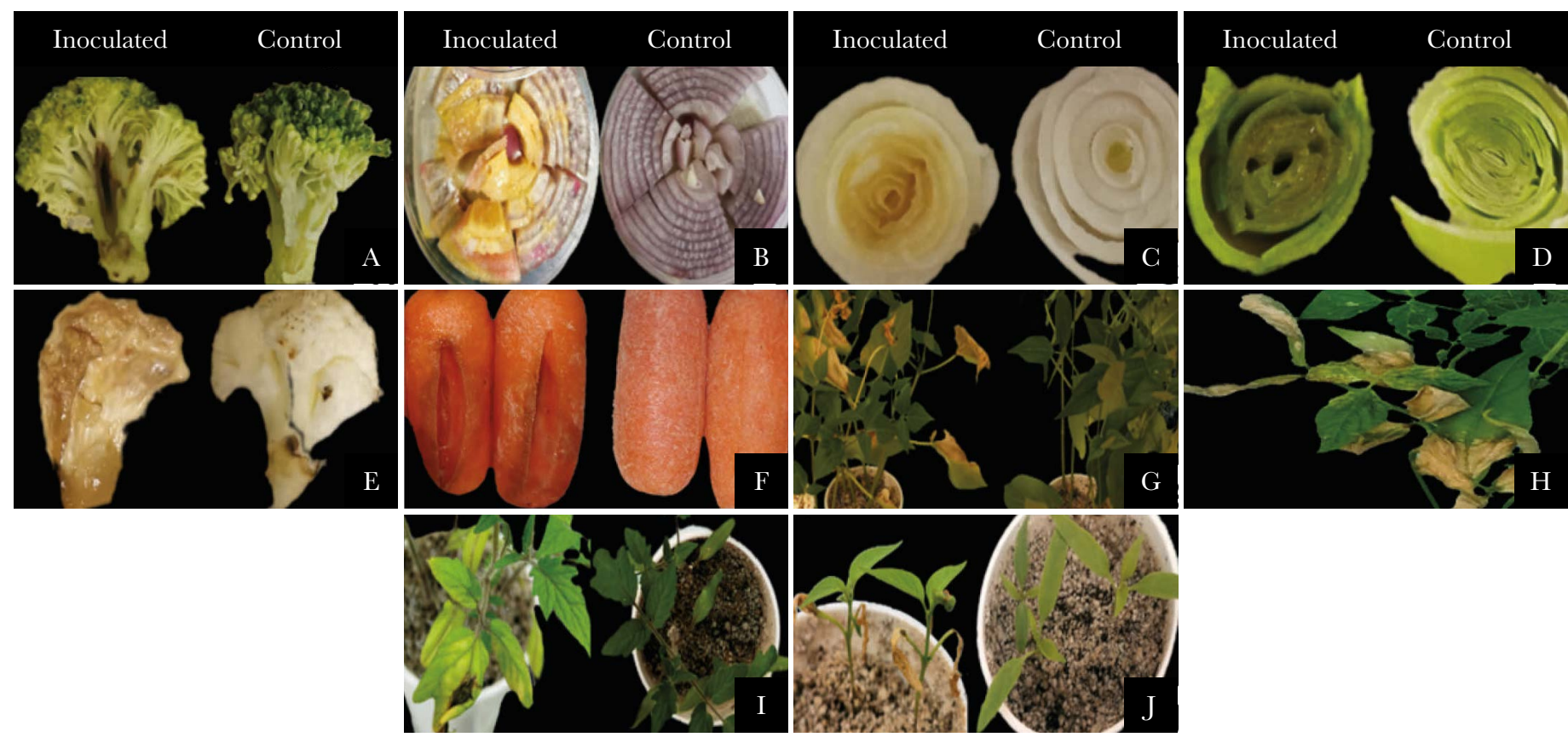

Figure 2. Symptoms caused by Pseudomonas viridiflava. In vitro rot in vegetables: A) broccoli, B) red onion, G) spring onion, D) leek, E) cauliflower, and F) carrot. Greenhouse plants: G) and H) growth reduction and necrosis in bean leaves, I) necrosis and chlorosis in tomato, and J) necrosis in jalapeño pepper leaves.

The observed symptoms are in line with those reported for these plant species (EPPO, 2019). Growth reduction was observed in infected bean plants; P. viridiflava was originally isolated from bean plants with stunting symptoms in Switzerland (Goumans and Chatzaki, 1998). Likewise, stunting symptoms in alfalfa plants (Medicago sativa L.) infected with $P$. viridiflava were observed by Heydari et al. (2012). P. viridiflava pathogenicity and host range varies with the geographic location, plant susceptibility, and pathogen virulence; genetic populations of this pathogen include variants that differ in their proteolytic activity and exopolysaccharide production (Bartoli et al., 2014). No symptoms were developed by vegetables and control plants inoculated with sterile distilled water. From the tissue of infected vegetables and plants, colonies with the same morphological characteristics of $P$. viridiflava were re-isolated in pure culture, fulfilling Koch's postulates. The identity of the inoculated and re-isolated strain was confirmed by PCR, with the amplification and partial 16S rRNA gene sequencing, as well as the above mentioned protocol.

\section{In vitro sensitivity to bactericides}

Out of the 14 evaluated bactericides, $P$. viridiflava isolated from onion was sensitive under in vitro conditions to Final Bacter (gentamicin + oxytetracycline), Serenade (Bacillus amyloliquefaciens), and Quatz IV (quaternary ammonium) (Table 1). The above suggests that this strain has a high resistance capacity to commercial bactericides. Bartoli et al. (2014; 2015) identified phenotypes with variable bactericide resistance among $P$. viridiflava strains from different geographic origin and host. However, unlike our results, most strains were susceptible to copper, streptomycin, and oxytetracycline. B. amyloliquefaciens has proved 
to be effective in the control of $P$. viridiflava in Persian buttercups (Ranunculus asiaticus) (Fascella et al., 2012); meanwhile, quaternary ammonium is used to disinfect greenhouse facilities and tools.

\section{GONGLUSIONS}

Pseudomonas viridiflava is the causal agent of onion rot in Morelos, Mexico. Such vegetables as spring onions and leek may be potential new hosts. $P$. viridiflava isolated from onion in Morelos is resistant under in vitro conditions to different antibiotics and coppers. Currently, there is an important legal restriction for the antibiotic application in agriculture; therefore, the use of biological products like Serenade (B. amyloliquefaciens) and efficient disinfectants (e.g., quaternary ammonium) should be further evaluated in the field, in order to establish the optimal management of this pathogen.

\section{REFERENGES}

Al-Karablieh, N., Mutlak, I., \& Al-Dokh, A. (2017). Isolation and identification of Pseudomonas viridiflava, the causal agent of fruit rotting of Cucumis sativus. Jordan Journal of Agricultural Sciences, 13, 79-91. https:// doi.org/10.12816/0039717

Araki, H., Innan, H., Kreitman, M., \& Bergelson, J. (2007). Molecular evolution of pathogenicity-island genes in Pseudomonas viridiflava. Genetics, 177, 1031-1041. https://doi.org/10.1534/genetics.107.077925

Bartoli, C., Berge, O., Monteil, C. L., Guilbaud, C., Balestra, G. M., Varvaro, L., ... \& Morris, C. E. (2014). The Pseudomonas viridiflava phylogroups in the $P$. syringae species complex are characterized by genetic variability and phenotypic plasticity of pathogenicity related traits. Environmental Microbiology, 16, 2301-2315. https://doi.org/10.1111/1462-2920.12433

Bartoli, C., Lamichhane, J. R., Berge, O., Varvaro, L., \& Morris, C. E. (2015). Mutability in Pseudomonas viridiflava as a programmed balance between antibiotic resistance and pathogenicity. Molecular Plant Pathology, 16, 860-869. https://doi.org/10.1111/mpp.12243

Beiki, F., Busquets, A., Gomila, M., Rahimian, H., Lalucat, J., \& García-Valdés, E. (2016). New Pseudomonas spp. are pathogenic to citrus. PLoS One, 11, e0148796. https://doi.org/10.1371/journal.pone.0148796

Choi, O., Lee, Y., Kang, B., Kim, S., Bae, J., \& Kim, J. (2020). Bacterial shoot blight of sweet crab apple caused by Pseudomonas viridiflava. Forest Pathology, 50, e12603. https://doi.org/10.1111/efp.12603

de Jesús Yáñez, M., Fucikovsky, L., Lorbeer, J. W., González, A., \& Aranda, S. (2003). Erwinia chrysanthemi Burkholder, McFadden and Dimock and other phytobacteria causal agents of onion (Allium cepa L.) bulb decay, and their detection. Revista Mexicana de Fitopatología, 21, 189-198.

Fascella, S., Boeri, G. L., Cangelosi, B., Pasini, C., Benuzzi, M., \& Curir, P. (2012). Experiences of Biological Control of Pseudomonas viridiflava on Cut Flowers of Ranunculus asiaticus. In II International Symposium on Horticulture in Europe 1099 (pp. 291-295). https://doi.org/10.17660/actahortic.2015.1099.33

EPPO (European and Mediterranean Plant Protection Organization). (2019). Pseudomonas viridiflava. EPPO Global Database. Fecha de consulta: 9 de diciembre de 2019. Disponible en https:/gd.eppo.int/taxon/ PSDMVF

Gitaitis, R. D., Sanders, F. H., Diaz-Perez, J. C., \& Walcott, R. R. (2003). Integrated management of bacterial streak and bulb rot of onion. In Pseudomonas syringae and related pathogens (pp. 443-449). Springer, Dordrecht. https://doi.org/10.1007/978-94-017-0133-4_48

Gitaitis, R., MacDonald, G., Torrance, R., Hartley, R., Sumner, D. R., Gay, J. D., \& Johnson III, W. C. (1998). Bacterial streak and bulb rot of sweet onion: II. Epiphytic survival of Pseudomonas viridiflava in association with multiple weed hosts. Plant Disease, 82, 935-938. https://doi.org/10.1094/pdis.1998.82.8.935

Godfrey, S. A. C., \& Marshall, J. W. (2002). Identification of cold-tolerant Pseudomonas viridiflava and $P$. marginalis causing severe carrot postharvest bacterial soft rot during refrigerated export from New Zealand. Plant Pathology, 51, 155-162. https://doi.org/10.1046/j.1365-3059.2002.00679.x

Goumans, D. E., \& Chatzaki, A. K. (1998). Characterization and host range evaluation of Pseudomonas viridiflava from melon, blite, tomato, chrysanthemum and eggplant. European Journal of Plant Pathology, 104, 181-188.

González, A. J., Rodicio, M. R., \& Mendoza, M. C. (2003). Identification of an emergent and atypical Pseudomonas viridiflava lineage causing bacteriosis in plants of agronomic importance in a Spanish 
region. Applied and Environmental Microbiology, 69, 2936-2941. https://doi.org/10.1128/aem.69.5.29362941.2003

Hall, T. (2005). BioEdit: biological sequence alignment editor for Win95/98/NT/2K/XP. URL http://www. mbio. ncsu. edu/bioedit/bioedit. html.

Heydari, A., Khodakaramian, G., \& Zafari, D. (2012). Characterization of Pseudomonas viridiflava causing alfalfa root rot disease in Hamedan province of Iran. Journal of Plant Pathology and Microbiology, 3, 135. https://doi.org/10.4172/2157-7471.1000135

Hunter, J. E., \& Cigna, J. A. (1981). Bacterial Blight Incited in Parsnip by Pseudomonas marginalis and Pseudomonas viridiflava. Phytopathology, 71, 1238-1241.

Klančnik, A., Piskernik, S., Jeršek, B., \& Možina, S. S. (2010). Evaluation of diffusion and dilution methods to determine the antibacterial activity of plant extracts. Journal of Microbiological Methods, 81, 121-126. https://doi.org/10.1016/j.mimet.2010.02.004

Lelliott, R. A., \& Stead, D. E. (1987). Methods for the Diagnosis of Bacterial Diseases of Plants. Blackwell Scientific Publications, Oxford.

Macagnan, D., Romeiro, R. D. S., Macedo, D. M. D., \& Schurt, D. A. (2007). Podridão-mole em pós-colheita de batata (Solanum tuberosum) incitada por Pseudomonas viridiflava. Summa Phytopathologica, 33, 307-308. https://doi.org/10.1590/s0100-54052007000300019

Mansfield, J., Genin, S., Magori, S., Citovsky, V., Sriariyanum, M., Ronald, P., ... \& Foster, G. D. (2012). Top 10 plant pathogenic bacteria in molecular plant pathology. Molecular Plant Pathology, 13, 614-629. https://doi.org/10.1111/j.1364-3703.2012.00804.x

Nuebling, S., Schmidt, H., \& Weiss, A. (2016). Variation of the Pseudomonas community structure on oak leaf lettuce during storage detected by culture-dependent and-independent methods. International Journal of Food Microbiology, 216, 95-103. https://doi.org/10.1016/j.ijfoodmicro.2015.09.007

Sarris, P. F., Trantas, E. A., Mpalantinaki, E., Ververidis, F., \& Goumas, D. E. (2012). Pseudomonas viridiflava, a multi host plant pathogen with significant genetic variation at the molecular level. PloS one, 7, e36090. https://doi.org/10.1371/journal.pone.0036090

Schaad, N. W., Jones, J. B., \& Chun, W. (2001). Laboratory guide for the identification of plant pathogenic bacteria (No. Ed. 3). American Phytopathological Society (APS Press).

Serret-López, M., Aranda-Ocampo, S., Espinosa-Victoria, D., Ortiz-Martínez, L. E., \& Ramírez-Razo, K. (2021). Polyphasic characterization of Burkholderia gladioli isolated from onion and evaluation of its potential pathogenicity for other crops. Revista Mexicana de Fitopatología, 39, 21-40. https://doi. org/10.18781/r.mex.fit.2007-2

TecnoAgro. (2017). La producción de cebolla en México. Revista en línea 119. Disponible en 14 https:// tecnoagro.com.mx/no.-119/la-produccion-de-cebolla-en-mexico

Tsuji, M., \& Shinichi, F. (2021). The first report of bacterial streak and rot of onion caused by Pseudomonas viridiflava in Japan. Plant Disease, (ja). https://doi.org/10.1094/pdis-02-21-0296-pdn

William, S., Feil, H., \& Copeland, A. (2012). Bacterial genomic DNA isolation using CTAB. Sigma, 50 (6876).

Weisburg, W. G., Barns, S. M., Pelletier, D. A., \& Lane, D. J. (1991). 16S ribosomal DNA amplification for phylogenetic study. Journal of Bacteriology, 173, 697-703. https://doi.org/10.1128/jb.173.2.697-703.1991

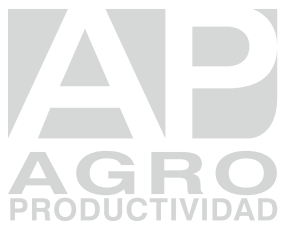

